УДК 347.232 .4

DOI https://doi.org/10.32844/2618-1258.2019.5-2.8

ЗУБАЧИК Н.Б.

\title{
ПРОБЛЕМИ НАБУТТЯ ПРАВА ВЛАСНОСТІ НА ЗЕМЕЛЬНІ ДІЛЯНКИ ЗА НАБУВАЛЬНОЮ ДАВНІСТЮ
}

Стаття присвячена дослідженню правового регулювання набуття права власності на земельну ділянку за набувальною давністю та правозастосовної практики. Виокремлено проблемні питання, зокрема доведено недосконалість норми, яка при дотриманні умов набувальної давності скеровує особу до загального порядку безоплатного набуття права власності на земельну ділянку. Проаналізовано позиції науковців та судову практику із досліджуваного питання. Обгрунтовано можливість застосування набувальної давності як підстави набуття права власності на земельну ділянку, яка сформована як об'єкт цивільних прав, має визначену площу, межі, визначені щодо неї права, а після створення Державного земельного кадастру зареєстрована в ньому та якій присвоєний кадастровий номер. Визначено умови набувальної давності для земельних ділянок та тривалість давнісного володіння. Такими умовами варто вважати добросовісне заволодіння земельною ділянкою, відкрите та безперервне володіння нею протягом встановленого строку. Запропоновано встановити строк давнісного володіння земельною ділянкою для набуття права власності, як і для іншого нерухомого майна тривалістю в 10 років. Підтверджено необхідність звернення особи в загальному порядку для набуття права власності на земельну ділянку, якщо ділянка не сформована як об'єкт цивільних прав навіть за умови, якщо така особа зайняла частину земної поверхні і відкрито та безперервно користується нею понад 15 років. Піддано критиці положення ЗК України, за яким набути у власність земельну ділянку за набувальною давністю може лише громадянин. Окреслено коло суб'єктів набувальної давності на земельну ділянку, якими можуть бути фізичні та юридичні особи. При цьому мають бути дотримані встановлені законом обмеження щодо можливості набуття певними категоріями осіб права власності на певні види земельних ділянок. Запропоновано зміни до ст. 119 ЗК України для запровадження дієвого механізму набуття права власності на земельні ділянки за набувальною давністю.

Ключові слова: земельна ділянка, набуття права власності, набувальна давність, добросовісне заволодіння, відкрите та безперервне володіння.

The article is devoted to the study of legal regulation of acquisition of ownership of the land plot according to the acquisitive prescription and law enforcement practice. Problematic issues were identified, in particular, the imperfection of the norm was proved, which, under the conditions of usucaption, directs a person to the general procedure of free acquisition of ownership of land. Scientists' positions and case law on the subject are analyzed. The author proves possibility of using the acquisitive prescription as a basis for acquiring the ownership of a land plot, which is formed as an object of civil rights, has a defined area, boundaries determined in relation to it, and after the creation of the State Land Cadastre - which is registered in it and to which it is assigned a cadastral number. The conditions of the usucaption for the land plots and the duration of the ancient possession are determined. Such conditions should be considered: fair possession of the land, open and continuous possession of it for a fixed period. It is proposed to set the term of acquisitive prescription of the land plot for the acquisition of property rights as for other real estate lasting 10 years. The necessity for a person to use general order to acquire ownership of a land plot was confirmed, unless the plot was formed as an object of civil rights, even if such a person occupied part of the earth's surface and used

(C) ЗУБАЧИК Н.Б. - аспірант кафедри цивільного права та процесу (Львівський національний університет імені Івана Франка) 
it openly and continuously for more than 15 years. The provision of the Land Code of Ukraine has been criticized, according to which only a citizen can acquire a land plot according to the acquisitive prescription. The circle of subjects of usucaption on the land plot is outlined, which can be natural and legal persons. At the same time, the statutory restrictions on the possibility of acquiring certain categories of person's ownership of certain types of land must be observed. Changes to Art. 119 of the Land Code of Ukraine for the introduction of an effective mechanism of acquisition of ownership of land plots by acquisitive prescription are proposed.

Key words: land plot, acquisition of ownership, acquisitive prescription (usucaption), conscientious possession, open and continuous ownership.

Вступ. Серед об'єктів права власності окреме та важливе місце займають земельні ділянки. Право власності на них може набуватися на підставах, визначених законом, у тому числі за набувальною давністю. Ст. 344 ЦК України «Набувальна давність» навіть окремо виділяє земельні ділянки серед об'єктів набувальної давності, водночас вказуючи, що порядок набуття права власності за набувальною давністю на них регулюється спеціальним законом. Ст. 119 ЗК України замість врегулювання особливостей такого набуття просто відсилає до загального порядку безоплатного набуття права власності на земельні ділянки, при якому вирішення питання про передання особі земельної ділянки у власність $є$ компетенцією органу державної влади чи органу місцевого самоврядування, для якого дотримання особою умов набувальної давності не має обов'язкового значення. Така конструкція статті фактично виключає можливість набуття права власності на земельну ділянку за набувальною давністю, деякі автори навіть назвали цю норму «мертвою» [1, с. 276]. Приблизно так само вказану норму сприймає і судова практика.

Набувальну давність як підставу набуття права власності досліджували такі вчені, як П.Д. Гуйван, В.П. Маковій, К.І. Скловський, В.І. Цікало, Г.Ф. Шершенєвич та ін. Однак дослідження зазначених вчених стосувалися загальних питань набувальної давності і не приділяли увагу особливостям набуття права власності за цією підставою на земельні ділянки.

Недосконале законодавче регулювання досліджуваних правовідносин, відсутність позитивної судової практики та комплексного доктринального вирішення вказаних проблем породжують необхідність подальших наукових досліджень.

Постановка завдання. Метою статті є виявлення прогалин і суперечностей у законодавчому регулюванні набуття права власності на земельну ділянку за набувальною давністю, проблем у правозастосовній практиці та внесення пропозицій щодо удосконалення відповідних норм права та правових висновків Верховного Суду.

Результати дослідження. У ст. 344 ЦК України, яка передбачає підстави та порядок набуття права власності за набувальною давністю, зазначено, що набуття права власності на земельну ділянку за набувальною давністю регулюється законом. Тобто ЦК України зараховує земельні ділянки до об'єктів, право власності на які може набуватися за набувальною давністю, однак для 3'ясування підстав та порядку такого набуття відсилає до спеціального закону, яким є ЗК України.

Згідно $з$ ч. 1 ст. 119 ЗК України громадяни, які добросовісно, відкрито і безперервно користуються земельною ділянкою протягом 15 років, але не мають документів, які б свідчили про наявність у них прав на цю земельну ділянку, можуть звернутися до органу державної влади, Ради міністрів Автономної Республіки Крим або органу місцевого самоврядування 3 клопотанням про передачу її у власність або надання в користування. Розмір цієї земельної ділянки встановлюється в межах норм, визначених цим Кодексом.

Як бачимо, норма спеціального закону сформульована таким чином, що особа, яка виконала всі умови набувальної давності щодо земельної ділянки та претендує на набуття за цією підставою права власності на неї, не набуває право, а лише може в загальному порядку звертатися до органів державної влади чи органів місцевого самоврядування щодо передання їй цієї ділянки у власність. Але ж у такому разі підставою набуття права власності буде не набувальна давність, а рішення відповідного органу. О.П. Печений влучно зазначає, що в такому разі законодавцю варто говорити про все, що завгодно, але не про набувальну давність, юридичним ефектом якої якраз є виникнення права власності, а не можливості його набуття [2, с. 251].

У науковій літературі немає єдності думок у питанні можливості набуття права власності на земельні ділянки за набувальною давністю. 
О.П. Сергєєв вважає, що, незважаючи на те, що земельні ділянки практично не можуть бути визнані безхазяйним майном, застосування цього правила не виключає можливості набуття права власності на них на підставі набувальної давності [3, с. 234].

Деякі автори вказують на те, що набуття права власності за набувальною давністю на земельну ділянку можливе в разі дотримання умов набувальної давності, якими є добросовісність, відкритість та безперервність користування ділянкою протягом понад 15 років [4, с. 276].

М.О. Духно та Г.В. Чубуков вважають, що інститут набувальної давності до земельних ділянок підлягає застосуванню, але в обмежених законом випадках (наприклад, до земель, власник яких невідомий). Землі, які перебувають у державній або комунальній власності, до таких не належать. Фактичне, не дозволене власником користування земельною ділянкою, яка є державною чи комунальною власністю, визнається протиправною дією (самовільне зайняття земельної ділянки), і в таких випадках інститут набувальної давності застосовуватися не може [5, с. 80-82].

На думку О.А. Галіновської, об'єктом виникнення права власності на підставі набувальної давності не можуть бути земельні ділянки, які за нормами земельного законодавства не можуть бути об’єктами права приватної власності і належать тільки державі [6, с. 90].

Натомість, на думку О.К. Голіченкова, набувальна давність не може бути підставою виникнення прав на земельну ділянку, оскільки громадянин або юридична особа, які не є власниками земельної ділянки, хоч і володіють нею як своїм власним нерухомим майном добросовісно, відкрито та безперервно, не набувають право власності на цю земельну ділянку, незалежно від строків володіння [7, с. 67].

А.М. Мірошниченко та P.I. Марусенко зазначають, що ст. 119 ЗК України фактично виключає можливість застосування положень про набувальну давність до відносин із земельними ділянками. На думку авторів, можливість звернення до органу державної влади або органу місцевого самоврядування щодо передання особі у власність або користування земельної ділянки на підставі ст. 119 ЗК України абсолютно не залежить від дотримання вимог, зумовлених цією нормою (строку та характеру користування). Крім того, дотримання цих умов не означає обов'язкового задоволення поданої заяви $[1$, с. 276].

Аналогічну позицію висловив у постанові від 11 квітня 2018 р. у справі № 742/2916/15-ц Касаційний цивільний суд у складі Верховного Суду, який дійшов висновку, що не передбачено жодних переваг для осіб, зазначених у ч. 1 ст. 119 ЗК України, оскільки навіть дотримання всіх умов набувальної давності не призводить до виникнення права власності на землю та фактично відсилає до загального порядку надання земельних ділянок у власність або в користування (ст. ст. 118, 123 ЗК України). Ця норма надає лише право звернення до органу державної влади або місцевого самоврядування з клопотанням про передачу земельної ділянки у власність чи користування і не передбачає обов'язкової передачі земельної ділянки у власність чи користування таким особам при дотриманні передбаченої законом процедури звернення та подання необхідних документів [8].

Доволі суперечливі правові висновки щодо застосування ст. 119 ЗК України зроблені Великою палатою Верховного Суду в постанові від 15 травня 2019 р. у справі № 729/608/17. 3 одного боку, Велика палата визначила умови набуття права власності на земельну ділянку за набувальною давністю: 1) добросовісність користування земельною ділянкою, яке полягає у невчиненні особою перешкод власнику земельної ділянки в реалізації ним свого права власності на це майно протягом 15 років; 2) відкритість користування, яке має бути очевидним для усіх інших осіб; 3) безперервність користування протягом 15 років; 4) відсутність документів, які б свідчили про наявність у громадянина прав на цю земельну ділянку. Здавалося б, такий підхід передбачає можливість набуття права власності на земельну ділянку за набувальною давністю в разі дотримання перелічених умов. Однак після цього Велика палата одразу «пригадала» раніше висловлені Верховним Судом позиції і вказала, що порядок безоплатного набуття земельних ділянок передбачений ст. 118 ЗК України, та іншого порядку законом не встановлено, а передання земельних ділянок у власність або в користування $€$ компетенцією органів державної влади та органів місцевого самоврядування [9].

Формулювання чинної редакції ст. 119 ЗК України та правові висновки Верховного Суду щодо іiі застосування по суті заперечують можливість виникнення права власності на земельну ділянку на підставі набувальної давності.

Тим самим земельні ділянки безпідставно вилучаються із кола об’єктів набувальної давності, а особи, які виконали умови набувальної давності, позбавляються змоги перетворити фактичний стан на правовий титул та втрачають ефективний механізм усунення правової невизначеності щодо майна. 
Для повного розуміння можливості застосування набувальної давності як підстави набуття права власності на земельну ділянку, насамперед, необхідно звернутися до визначення земельної ділянки, яке міститься у ч. 1 ст. 79 ЗК України: це частина земної поверхні з установленими межами, певним місцем розташування, визначеними щодо неї правами.

Законом України «Про державний земельний кадастр» доповнено ЗК України ст. 79-1 (у чинній редакції «Земельна ділянка як об’єкт цивільних прав»), якою детальніше визначено ознаки земельної ділянки. Так, згідно з положеннями зазначеної статті формування земельної ділянки полягає у визначенні земельної ділянки як об'єкта цивільних прав. Формування земельної ділянки передбачає визначення іiї площі, меж та внесення інформації про неї до Державного земельного кадастру. Сформовані земельні ділянки підлягають державній реєстрації в Державному земельному кадастрі, а сформованою ділянка вважається з моменту присвоєння йй кадастрового номера.

Тому об’єктом набуття права власності за набувальною давністю може бути лише земельна ділянка, яка в розумінні ЗК України як така може бути об'єктом цивільних прав (із визначеною площею, межами та визначеними щодо неї правами), а після запровадження системи Державного земельного кадастру - яка зареєстрована у ньому та якій присвоєний кадастровий номер.

Тобто, якщо особа заволоділа не земельною ділянкою в розумінні ЗК України, а зайняла частину земної поверхні без установлених меж та визначених щодо неї прав, то таке зайняття не може вважатися добросовісним заволодінням земельною ділянкою та не розпочинає перебігу набувальної давності. У такому разі навіть якщо особа добросовісно, відкрито та безперервно користувалася землею більше 15 років, для набуття права власності необхідно застосовувати загальний порядок, бо ділянка ще не є сформованою як об'єкт цивільних прав та є частиною земель державної або комунальної власності. Не може право власності на об'єкт виникнути раніше самого об'єкта.

Як і щодо інших об’єктів, набуття права власності на земельну ділянку за набувальною давністю можливе в разі дотримання певних умов. Насамперед, ст. 344 ЦК України наголошує, що положення про набувальну давність можуть бути застосовані лише щодо особи, яка добросовісно заволоділа чужим майном. У ЦК України не надано визначення поняття «добросовісне заволодіння». У ст. 388 лише визначено, що добросовісним варто вважати набувача, який придбав майно за відплатним договором в особи, яка не мала права його відчужувати, про що набувач не знав і не міг знати.

У ч. 1 ЗК України зазначено не лише про обов'язкове добросовісне заволодіння земельною ділянкою, але й про добросовісне користування нею протягом усього строку давнісного володіння. Вважаємо, що критерій добросовісності може бути застосований лише до заволодіння майном, оскільки саме в цей момент особа визначає на свій розсуд та надає суб'єктивну оцінку тому, чи своїм заволодінням майном вона не порушує прав інших осіб. У подальшому заволодіння переходить у триваючий стан - володіння, добросовісність якого залежить від моменту заволодіння та з часом не змінюється.

У літературі зверталася увага на ту обставину, що неможливим є добросовісне заволодіння земельною ділянкою, що належить фізичній особі, яка не здійснювала відмову від права власності, або державі чи територіальній громаді, оскільки такою ділянкою набувачу потрібно заволодіти самовільно, що є протиправною дією [10, с. 47].

3 огляду на наведене, може виникнути питання, в яких випадках взагалі можливе добросовісне безтитульне заволодіння чужою земельною ділянкою? До прикладу, в разі смерті фізичної особи - власника земельної ділянки, якщо після смерті цієї особи ніхто не прийняв спадщину і спадщина не визнана відумерлою у встановленому законом порядку.

Також слід звернути увагу та ту обставину, що ЗК України як на умову набувальної давності вказує на користування земельною ділянкою не менш ніж 15 років. На нашу думку, такою умовою варто вважати не користування, а володіння ділянкою протягом встановленого законом строку.

Давнісне володіння земельною ділянкою має також бути відкритим та безперервним. Володіння $є$ відкритим, якщо особа здійснює фактичне панування над річчю у звичайний для такої речі спосіб та не приховує факт знаходження майна в їі володінні. Безперервним $є$ володіння, яке не переривалось протягом всього строку набувальної давності. Особа, яка заявляє про давність володіння, може приєднати до часу свого володіння увесь час, протягом якого цим майном володіла особа, чиїм спадкоємцем (правонаступником) вона є. Разом із тим приєднати до строку володіння можна лише строк, протягом якого майном володів універсальний правопопередник спадкодавець або юридична особа. 
На нашу думку, немає необхідності встановлювати тривалість давнісного володіння земельною ділянкою для набуття права власності у 15 років, як це нині зроблено у ЗК України. Як і на інші об’єкти нерухомого майна, його достатньо встановити тривалістю у 10 років.

Недосконалим є також визначення у чинній редакції ст. 119 ЗК України суб'єкта набувальної давності на земельну ділянку - «громадянин». На нашу думку, таке формулювання безпідставно звужує коло осіб, які можуть набути земельну ділянку у власність за набувальною давністю, оскільки ними можуть бути усі фізичні особи та юридичні особи, якщо інше не встановлено ЗК України. Зокрема, буде діяти обмеження щодо можливості набуття іноземцем за набувальною давністю права власності на земельну ділянку сільськогосподарського призначення.

Висновки. За набувальною давністю може набуватися право власності на земельні ділянки, які є сформованими як об'єкти цивільних прав за умови добросовісного заволодіння та відкритого і безперервного володіння ними протягом встановленого законом строку. Для запровадження дієвого механізму такого набуття необхідно внести зміни у ст. 119 ЗК України, виклавши іiї ч. 1 у такій редакції: «Особа, яка добросовісно заволоділа чужою земельною ділянкою, визначеною як об'єкт цивільних прав і продовжує відкрито, безперервно володіти нею протягом 10 років, набуває право власності на цю земельну ділянку (набувальна давність), якщо інше не встановлено цим Кодексом». Ч. 2 цієї статті варто викласти у такій редакції: «Право власності за набувальною давністю на земельну ділянку набувається за рішенням суду. В інших випадках передання земельної ділянки у власність або користування здійснюється в порядку, встановленому цим Кодексом».

\section{Список використаних джерел:}

1. Мірошниченко А.М., Марусенко Р.І. Науково-практичний коментар Земельного кодексу України. Київ : Правова єдність, 2009. 496 с.

2. Харьковская цивилистическая школа: право собственности : монография / под ред. И.В. Спасибо-Фатеевой. Харьков : Право, 2012. 424 с.

3. Комментарий к Гражданскому кодексу Российской Федерации. Часть первая [Текст] / под ред. А.П. Сергеева. Москва : Проспект, 2010.

4. Науково-практичний коментар до Земельного кодексу України. Підготовлено в рамках спільного проекту Програми розвитку ООН та Міністерства юстиції України «Юридичне забезпечення прав і можливостей бідних» / A. Мартин. Київ, 2012. 145 с. URL: https://www.academia.edu/28568822/Науково-практичний_коментар_до_земельного_кодексу_ україни.

5. Духно Н.А., Чубуков Г.В. Земельный правопорядок и ответственность. Москва : Изд-во Института защиты предпринимателя, 1998.

6. Галиновская Е.А. Приобретательная давность как основание приобретения права собственности на земельный участок. Комментарий судебной практики. Вып. 5 / Под ред. К.Б. Ярошенко. Москва, 1999.

7. Голиченков А.К., Козырь О.М. Концепция Федерального закона о земле. Государство и право. 1994. № 7. С. 60-69.

8. Постанова Касаційного цивільного суду у складі Верховного суду від 11 квітня 2018 р. у справі № 742/2916/15-ц. URL: http://reyestr.court.gov.ua/Review/73627618

9. Постанова Великої палати Верховного суду від 11 квітня 2018 року від 15 травня 2019 р. у справі № 729/608/17. URL: http://www.reyestr.court.gov.ua/Review/82095850

10. Актуальные проблемы гражданского права : учеб. пособие / под ред. Н.М. Коршунова, Ю.Н. Андреева, Н.Д. Ериашвили. 2-е изд., перераб. и доп. Москва : ЮНИТИ-ДАНА: Закон и право, 2010. $431 \mathrm{c}$. 